\title{
Morphological Diversity in Gboma Eggplant (Solanum macrocarpon) as Assessed with Conventional and Tomato Analyzer Descriptors
}

\author{
Mariola PLAZAS $^{1)}$, Isabel ANDÚJAR ${ }^{1)}$, Santiago VILANOVA ${ }^{1)}$, Pietro GRAMAZIO ${ }^{11}$, Francisco Javier HER- \\ RAIZ $^{1)}$, Jaime PROHENS ${ }^{1 *}$ \\ ${ }^{1)}$ Instituto de Conservación y Mejora de la Agrodiversidad Valenciana, Universitat Politècnica de Valèn- \\ cia, Camino de Vera 14, Valencia, Spain. \\ ${ }^{*}$ Coresponding author, e-mail:jprohens@btc.upv.es
}

Bulletin UASVM Horticulture 71(2) / 2014

Print ISSN 1843-5254, Electronic ISSN 1843-5394

DOI:10.15835/buasvmcn-hort:10296

\begin{abstract}
The vegetable crop gboma eggplant (Solanum macrocarpon) and its wild ancestor S. dasyphyllum are native to Africa. Although it is an important crop in certain areas, there are few studies on gboma eggplant diversity and breeding. We have studied the morphological diversity of a collection of 11 accessions of S. macrocarpon and 1 accession of $S$. dasyphyllum using conventional descriptors for common eggplant ( $S$. melongena) as well as the phenomics tool Tomato Analyzer. Results revealed that the gboma eggplant collection studied is highly diverse, with significant differences among accessions for 27 traits. Also, significant differences were found between $S$. macrocarpon and $S$. dasyphyllum for 14 traits, revealing that both species present considerable morphological differences. The large diversity found in the collection found indicates that selection and breeding can result in considerable improvement in this crop. Results also reveal that common eggplant descriptors and Tomato Analyzer are adequate tools to describe the variation present in gboma eggplant.
\end{abstract}

Keywords: diversity, genetic resources, phenomics, Solanum macrocarpon, Tomato Analyzer

Introduction. Gboma eggplant (Solanum macrocarpon L.) is a vegetable crop native to sub-Saharan Africa and used for its edible fruits and leaves (Schippers, 2000). Despite its local importance in several countries and areas of West Africa it has largely remained neglected by the scientific and breeders communities. The cultivated $S$. macrarpon was domesticated from the wild relative $S$. dasyphyllum Schum. and Thonn. and hybrids between both species are fertile (Bukenya and Carasco, 1994). In consequence, the latter is a genetic resource for gboma eggplant breeding. Also, gboma eggplant is a relative of common eggplant ( $S$. melongena L.) and sexual interspecific hybrids between both species can be obtained, although with limited fertility (Oyelana and Ugborogho, 2008). Knowledge of the diversity of this crop is essential for detecting sources of variation for breeding programmes either of gboma eggplant or of common eggplant.
Aims and objectives. This work is aimed at studying the morphological diversity of the gboma eggplant and its relationship to the wild $S$. dasyphyllum. It will also allow determining if conventional standardized eggplant descriptors specifically developed for common eggplant (IBPGR, 1990) and the phenomics tool Tomato Analyzer (Brewer et al., 2006) are appropriate tools for gboma eggplant characterization and diversity studies.

Materials and methods. Eleven gboma eggplant accessions originally collected in Africa plus one accession of its wild ancestor (S. dasyphyllum) were evaluated. Five plants per accession were cultivated under open field conditions at Valencia (Spain) using a completely randomized design. Individual plants characterized with 18 conventional morphological descriptors (IPGRI, 1990) and longitudinally cut fruits were scanned and subjected to morphometric analysis for 24 
Tab. 1. Mean, minimum and maximum values for selected traits in 11 accessions of the cultivated $S$. macrocarpon and in one accession of its wild ancestor S. dasyphyllum.

\begin{tabular}{ccccc}
\hline Trait & Leaf prickles $^{\mathrm{a}}$ & $\begin{array}{c}\text { Anthocyanin } \\
\text { pigmentation }^{\mathrm{b}}\end{array}$ & $\begin{array}{c}\text { Fruit weight } \\
\text { (g) }\end{array}$ & $\begin{array}{c}\text { Fruit length/ } \\
\text { width ratio }\end{array}$ \\
\hline S. macrocarpon $(\mathrm{n}=11)$ & & & & \\
\hline Mean & 0.99 & 1.27 & 119 & 0.767 \\
\hline Minimum & 0.00 & 0.00 & 54 & 0.678 \\
\hline Maximum & 3.80 & 7.00 & 177 & 1.336 \\
\hline S. dasyphyllum $(\mathrm{n}=1)$ & 9.00 & 0.00 & 22 & 0.796 \\
\hline
\end{tabular}

a Measured on a prickliness scale $(0=$ no prickles; $9=$ very many $(>20))$.

${ }^{\mathrm{b}}$ Measured on a anthocyanin pigmentation scale $(0=$ absent; $9=$ very strong).

fruit shape traits with Tomato Analyzer (Brewer et al., 2006). Data were subjected to ANOVA tests and to principal components analysis (PCA).

Results and Discussion. A large diversity was found in the gboma eggplant collection for both conventional and Tomato Analyzer descriptors. Significant differences among accessions were found for 27 traits, of which 13 corresponded to plant descriptors and 14 to Tomato Analyzer descriptors. High differences were found for some traits, like anthocyanin pigmentation, prickliness, and fruit weight (Table 1). Although most accessions presented the typical flattened or subspherical fruit shape (Schippers et al., 2000), with a fruit length/width ratio below 0.8 , one $S$. macrocarpon accession had elongated fruit shape with a fruit length/width ratio above 1.3 (Table 1). Significant differences for 14 traits were found between $S$. macrocarpon and $S$. dasyphyllum. Most relevant differences between the cultivated $S$. macrocarpon and its wild ancestor (Bukenya and Carasco, 1994) were related to the higher prickliness and smaller fruit size of $S$. dasyphyllum (Table 1). PCA analyses clearly separated both species; the odd elongated $S$. macrocarpon was also separated from the rest of accessions, which group into two clusters, in the PCA graph.

Conclusion. Gboma eggplant is a highly diverse species, indicating that there is ample room for selection and breeding. The wild $S$. dasyphyllum is clearly distinct from $S$. macrocarpon in morphological and fruit shape traits. Finally, both conventional morphological descriptors and phenomics Tomato Analyzer descriptors have demonstrated being useful for characterizing the genetic resources of this neglected crop.

Acknowledgments. This research has been partially funded by Ministerio de Economía y Competitividad and FEDER (grant AGL201234213). Pietro Gramazio is grateful to Universitat Politècnica de València for a pre-doctoral grant.

\section{REFERENCES}

1. Brewer MT, Lang L, Fujimura K, Dujmovic N, Gray S and van der Knaap E (2006). Development of a controlled vocabulary and software application to analyse fruit shape variation in tomato and other plant species. Plant Physiol. 141:15-25.

2. Bukenya ZR and Carasco JF (1994). Biosystematic study of Solanum macrocarpon-S. dasyphyllum complex in Uganda and relations with S. linneanum. East Afr. Agric. Forest J 59:187-204.

3. IBPGR (1990). Descriptors for eggplant, International Board for Plant Genetic Resources, Rome, Italy.

4. Oyelana OA and Ugborogho RE (2008). Phenotypic variation of $\mathrm{F} 1$ and $\mathrm{F} 2$ populations from three species of Solanum L. (Solanaceae). Afr. J. Biotechnol. 7:2359-2367.

5. Schippers RR (2000). African indigenous vegetables, an overview of the cultivated species, Natural Resources Institute, Chatham, UK. 